\title{
Impact of Mobile Phone Usage on Psychosocial Wellbeing of Student Nurses
}

\author{
Parul Maurya ${ }^{1}$, Yogita Penuli ${ }^{2}$, Ashutosh Kunwar $^{3}$, Hemlata Lalia $^{4}$ Versha Negi ${ }^{5}$ \\ Anjana Williams" Vandana Thakur* \\ 1,2,3,4,5 Student nurses of Himalayan College of Nursing, Dehradun, SRH University Uttarakhand, India \\ *Senior Nursing Tutor, Mental Health Deptt. Himalayan College of Nursing, SRH University, Dehradun, \\ Uttarakhand \\ *Clinical instructor,Himalayan College of Nursing, Dehradun, SRH UniversityUttarakhand, India
}

\begin{abstract}
AQuantitative Non experimental, cross sectional survey was conducted to assess the impact of mobile phone usage on the psychosocial wellbeing of student nurses. The study was conducted on 193 student nurses in the College of Nursing in Northern India. Samples were selected by stratified random sampling technique. The study results showed that $80 \%$ of the subjects were in the age group of 17 to 26 years. Out of the total subjects, $89 \%$ were females. The Participants had been using mobile phones since for the last 4 years. On an average, $76 \%$ subjects spent 1 to 3 hrs. on mobile usage. Statistical significant association was found between Attention and concentration with age of participants. Gender was also found to have statistical significance with Socialization and communication. Females used phone more for socialization and communication. Highest mean SD was $17.42 \pm 4.33$ for attention and concentration. Hence it can be concluded that usage of mobile phone certainly has an impact on psychosocial well-being of student nurses.
\end{abstract}

Keywords: Psychosocial Wellbeing, Mobile Phone Usage

\section{Introduction}

"It has become appallingly obvious that our technology has exceeded our humanity" These words of Albert Einstein are very true and are proving their worth with a dramatic increase in mobile phone usage in recent years. It has increased the attraction of young customers and has become a great issue nowadays. ${ }^{1}$ In today's world, many adolescents use Internet, cell phones, television and other mass media methods as a part of their daily activity chores.

Technology is affecting adolescents' quality and quantity of sleep, their attention span and their academic performance. This has further caused attention deficit, difficulties in focusing and a negative impact on adolescent academic achievements. It is believed that mobile phones have the potential of occupying a central place in the daily lives of undergraduates. ${ }^{2}$ Research shows that there is a difference between students' performance and commitment to academics in lecture rooms from those who use mobile phones during lecture, inattentiveness, and non-participation in academic assignments or field works. ${ }^{3}$

Media has become an integral part of communication today. Everything which has public attention has its positive and negative effects. Students use mobile phones in lecture rooms to communicate with their friends. ${ }^{4}$ Usages of mobile phones adversely affect student concentration, psychosocial wellbeing and their physiological health which are areas that need attention. The problem is that the use of mobile phone among students has become a habit. Conscious effort is required to modify our present teaching methods in order to achieve the objective of teaching and learning process in the lecture room. ${ }^{3}$

The global cellular phone market estimates that there are 1.8 billion subscribers now. The constant connections afforded by cell phones undoubtedly have implications on an adolescent's present decisions and explorations. The increased popularity of cell phones in recent years has attracted research attention. ${ }^{4}$

The incredible growth of cell phone ownership among adolescents provides evidence that the social structure surrounding them considers this technology as important, if not necessary. Student nurses and professional nurses deal with life and death which need efficient concentration and communication skills to perform their activities effectively. ${ }^{5}$

\subsection{Statement of the Problem}

A cross sectional study to assess the impact of mobile phone usage on psychosocial well-being of student nurses in a selected Institution of Dehradun, Uttarakhand, India, 2013 


\subsection{Objectives}

- To measure the impact of mobile phone usage on psychosocial well-being of student nurses.

- To find the association between the impact of mobile phone usage on their selected personal profile variables.

\section{Material And Methods}

The present study was conducted on 28 April 2013 on 193 student nurses who were selected through stratified random sampling technique from a selected College of Nursing, Dehradun, Uttarakhand. The aim was to assess the impact of mobile phone usage on psychosocial well-being of participants. Psycho-social wellbeing tool was designed by the investigators and was validated by experts in the nursing field. The tool comprised four aspects which included1) Attention and Concentration, 2) Academic Performance, 3) Socialization and Communication and 4) Phone addiction. After taking necessary administrative permissions from the concerned authorities, data was collected from the participants. Written consent was also taken from the participants.

III. Results And Findings

3.1 Demographic Profile Distribution of respondents

Table no. 1 Frequency Percentage Distribution of the Participants

\begin{tabular}{|c|c|c|}
\hline SAMPLE CHARACTERISTICS & FREQUENCY (f) & PERCENTAGE (\%) \\
\hline \multicolumn{3}{|l|}{ Age In Years } \\
\hline $17-26$ & 155 & 80 \\
\hline $37-46$ & 9 & 5 \\
\hline 47- 56 & 14 & 7 \\
\hline \multicolumn{3}{|l|}{ Gender } \\
\hline Male & 22 & 11 \\
\hline Female & 171 & 89 \\
\hline \multicolumn{3}{|l|}{ Period Of Mobile Phone Usage } \\
\hline $1-4$ years & 112 & 58 \\
\hline $5-8$ years & 54 & 28 \\
\hline $9-12$ years & 21 & 11 \\
\hline $13-16$ years & 6 & 3 \\
\hline \multicolumn{3}{|l|}{ Average Time Used On Phone } \\
\hline $1-3 \mathrm{hrs}$ & 146 & 75.5 \\
\hline $4-6 \mathrm{hrs}$. & 42 & 22 \\
\hline 7--9 hrs. & 4 & 2 \\
\hline $10-12 \mathrm{hrs}$. & 1 & 0.5 \\
\hline
\end{tabular}

Table number 1 depicts that $80 \%$ respondents were in the age group of 17 to 26 years, as they were pursuing the professional course. All of the subjects had their own mobile phones as mobiles have become integral part of daily living. Majority of the subjects $89 \%$ were females, number of females were high as nursing is female dominant profession and there are less numbers of males.

Out of 193 subjects $58 \%$ had been using mobile phones for a period of 1 to 4 years. It can be inferred that the use of mobile phones have increased in recent times maybe because of free incoming and attractive outgoing communications. Out of the total participants $75.5 \%$ were spending 1 to 3 hours per day on mobile phones.

\subsection{Reason for Using Mobile Phones among respondents}

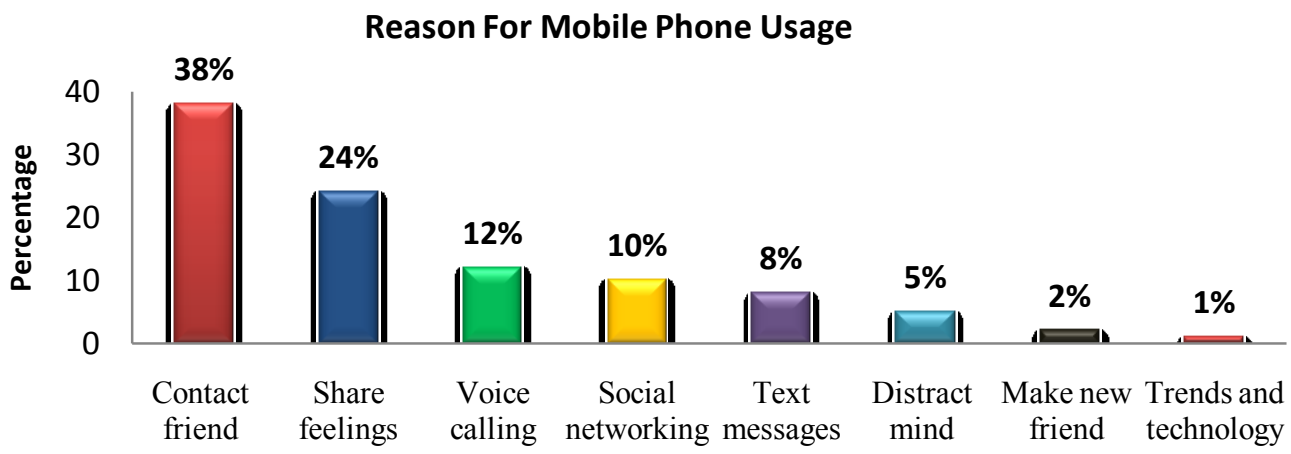

Graph no. 1 reason and percentage wise distribution of mobile phone usage respondents 
The Graph depicts that $38 \%$ of the subjects were using their mobile phones to contact friends, $24 \%$ were using phones to share their feelings with friends, only $12 \%$ were using it for voice calling to ventilate their feelings and to know the wellbeing of family and friends. It could be inferred that people mostly use phones to contact their friends, it has also been observed that less than ten percentages of subjects were using mobile phone for texting friends and family members;some were using it to making new friends and to chat with them on phone. Some were using it to follow the new trends and technology and respectively.

\subsection{Associations betweenaspects of Psychosocial wellbeingwith Personal Profile Variables of respondents} Table no. 2Associations between Attention and Concentration with Personal Profile Variables

\begin{tabular}{|c|c|c|c|c|}
\hline & At and above median & Below median & $\chi^{2}$ value & P Value \\
\hline \multicolumn{5}{|c|}{ Age in years } \\
\hline $\begin{array}{l}17-36 \\
37-53 \\
\text { Mobile }\end{array}$ & $\begin{array}{c}94 \\
6\end{array}$ & $\begin{array}{l}96 \\
17\end{array}$ & $4.50 *$ & 0.016 \\
\hline $\begin{array}{l}1-8 \mathrm{yr} . \\
9-16 \mathrm{yr}\end{array}$ & $\begin{array}{c}94 \\
7 \\
\end{array}$ & $\begin{array}{l}72 \\
20 \\
\end{array}$ & $8.77 *$ & 0.001 \\
\hline
\end{tabular}

Table no.2 depicts the statistical significance of Attention and Concentration with the age of the participants. There were more subjects between the ages of $17-36$ years. The period of using mobile phone was also statistical significant with Attention and Concentration of those respondents who were using the phones from one to eight years.

3.4Associations between aspects of Psychosocial wellbeingwith Personal Profile Variables of respondents Table no. 3 Association between Academic Performances and Personal Profile Variables

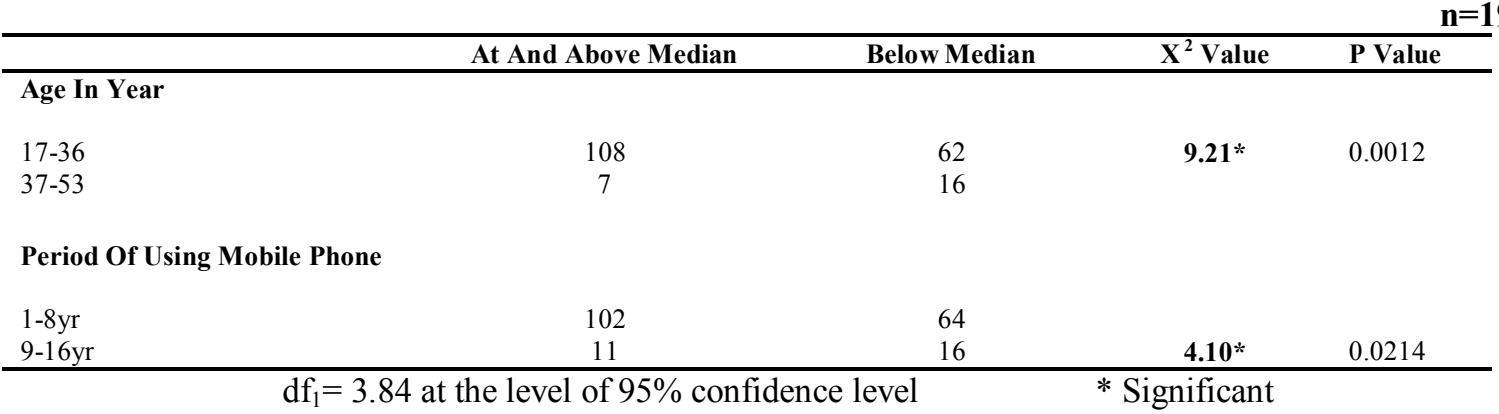

Table no.3 depicts the association between Academic Performances with the age of the respondents, and period of mobile phone usage with academic performance at the level of $p<0.05$. Hence it could be inferred thatacademic performance of the respondents is affected more in the age group of 17-36 years and the lessthe number of years of mobile phone usage the more is the impact on academic performance.

\subsection{Associations between aspects of Psychosocial wellbeingwith Personal Profile Variables of respondents Table no. 4Association between Socialization and CommunicationandPersonal Profile Variables}

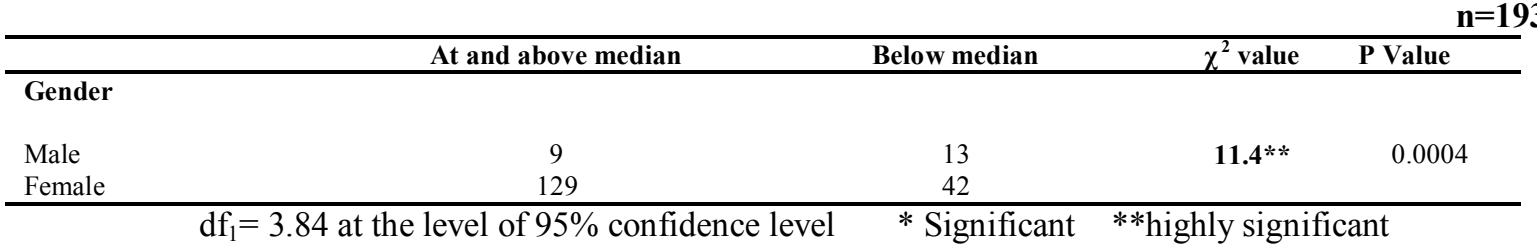

Table no.4 depicts a statistically high significance between the variables of Socialization, Communication with genderof the respondents. It can therefore be inferred that Socialization and Communication has an impact on female gender. Female does more communication and are socialize comparing to males. 


\section{Nursing Implications}

Mobile phone usage is on the rise and has great impact on psychosocial wellbeing of every individual.Since today's nursing students are tomorrow's staff nurses, educators, administrators, and supervisors, this study has got animportant implication for nurses. Mobile phones are vastly used which is affecting the attention and concentration of individuals. As a nurse it may affect the level of care by hampering the attention and concentration of a nurse.

Nurse administratorsneed to take interest in providing information about impact of mobile phone usage on psychosocial-wellbeing of individuals and health care workers. Nurses play an important part in health awareness and in order to provide information, nurses can plan to organize various types of workshops, role plays and other related programs to motivate public about harmful aspects of mobile phone usage particularly on attention and concentration.

This Research can make nurses and other health care professional aware of the harmful effects of mobile phone usage on various aspects of psychosocial well- being. The findings of the present study suggest that student nurses need to encouragecommunity people as well as staff nurses about the impact of mobile phone usage. Further interventional studies can be conducted to determine the harmful effects of mobile phone usage on health care professionals.

\section{Conclusion}

With a dramatic increase in mobile phone usage in recent years, usages of mobile phones have increased and havebecome animportant issue. Texting a friend is a tempting diversion that many students select over listening to a lecture or completing a class assignment, this distraction can have a negative impact on student's academic performance.

Today everyone usesmobile phones for one or the other purposes. This study concluded thatmobile phone usage has association with attention and concentration of student nurses which further may affect academic performance.

\section{Acknowlgement}

We would like to show our greatest appreciation for Dr. Sanchita Pugazhendi, Principal of Himalayan college of Nursing, Dehradun without the encouragement and guidance it would not have been possible to publish this article.

\section{References}

[1]. Chen YF.Social phenomenon of mobile phone use.Taiwan ; chia -yi ;2006 ;cited on may 4 2013;219-44:available from http://www.nhu.edu.tw/ society/jccic/11/fu/11-06.pdf

[2]. Kristin M. Dehmler .Adolescents usage of Internet, cell phones, television, and computer on a daily basis affecting adolescents' quality and quantity of sleep, their attention difficulties and their academic performance.july2009;Available from: https://ritdml.rit.edu/bitstream/handle/1850/10656/20943_pdf_18352_B0BAE164-98D5-11DE-BA8A-049CF0E6BF1D.pdf

[3]. Martin C. Cell phone usage and concentration during class.[ homepage on internet]; 2010 ,Dec, 14 available from :http://www.unh.edu/news/docs/2010CellphoneUsageStudy.pdf

[4]. Schreiner E. Effect of mobile phone on student [ homepage on internet] ;[cited on may 4 2013]; (603) 750-3020 [ internet] ;Available from :http://www.ehow.com/list_5977357_effects-mobile-phones-students.html

[5]. Aila I, Oncha o, Muhinat B, BrahimI .Use of mobile phone in lecture room. Journal of education and practices; 2012 0ct ;3; Available from: http://www.iiste.org/Journals/index.php/JEP/article/viewFile/2524/2540

[6]. Amali, Ismaila.Onche.O., Bello Muhinat, B.A Survey of University of Ilorin Students' Use of Mobile Phone in Lecture rooms and its Implications in Education for Nigeria Development.Journal of Education and Practice.ISSN 2222-1735 (Paper) ISSN 2222-288X (Online); 2012;3;Available from:http://www.iiste.org/Journals/index.php/JEP/article/viewFile/2524/2540

[7]. Heuberger B. Sociological Effects of the Cell Phone.2013; Available from: .http:/www.ehow.com/list 7773084_sociological-effects-cellphone.html 